\title{
ELECTRODEPOSITION
}

PUBLICATIONS BY THE STAEF OF THE UAIINAL BUREAU OF STAIDARDS.

(Revised to september 1, 1342).

\section{SCOPE OF ACTIVIIIES.}

The principal activities of the Bureau in the field of electrodeposition are as follows:

1. Researches upon the funäamental principles of electrodeposition.

2. Studies upon the quality and value of electroplated coatings and the clevelopment of specifications for use by the Government and incustry.

3. The development. of special processes and equipment required by other branches of the Government, such as the War, Navy, and Treasury Departments.

4. Investigation of the methoas of testing electroplated products and the solutions used in electrodeposition.

5. Testing of electroplated metals, such as hardware and. plumbing fixtures, that are purchased by the vederal Government on specifications. (Tests are not made for the ceneral public.).

6. Furnishing information to the Government and the public. Requests for information in this field that are not covered by the inclosed publications will receive careful attention.

In all the aoove activities tho Bureau cooperates airectly with othor Government agercies and with appropriate technical organizations, such as the American Elcctroplaters' Society, the Intornational Association of Electrotypors, and the American Society for Festing Materials.

\section{SCOPE OE IEIS LETIER CIRCULAR}

The publications that are listed in this circular are divided into three parts.

A - Government publications on electroplating, principally from the National Bureau of Standards. 

L.C. $625-\ddot{\# 2}$

FS - Federal Specifications that include definite requirements for electroplated coatings. (In certain cases, indiviaual agencies, especially the War and Navy Departnents, have separate specifications to meet their particular needs. Information.regarcing, such specirications may be obtained from the office of the Quartermaster General, War Department, Washington, D. C.; or the Burcau of Supjlies and Account's, Navy Department, Washington, D. C.

B - Papers from the National Bureau of Standarảs that were published in outside journals, files of which are available in many libraries.

In the first column, each paper is assigned a "réference number", purely for use in the index of this circular. This number should not be included in requests addressed to the superintendent of Documents, but only the "serial number" and title.

For convenience, a list "C" is aaded, of journals and books printed in the English language, that contain Information on electrodepasition.

The index contains reference to the principal subjects covered in lists $A$, $F S$, and $B$.

\section{PUBLICATIONS}

Government Publications:

List "A" inciudes in chronological order those papers published by the Government. Where the price is stated in the extreme righthand column, the publication can be purchased from the superintendent of Documents, Government Printing Office, Washington, D. C. The prices quoted are for delivery to addresses in the United States and its territories and possessions and in certain foreign countries which extend the franking privilege. In the case of all other countries, one-third or the cost of the publication should be added to cover postage. Remittances should be made either by coupons (obtainable from the superintendent of Documents in sets of 20 for $\$ 1.00$ and cood until usea), or by check or money order payable to the "Superintendent of Documents, Government Printing Office" and sent. to hin with order. Lotter' Circulars are obtainable, without charee, from the Bureau. Publications marked "OP" are out of print. Files of the Government publications will bo found in the larger librarios.

The explanation for the serial letters used for designating the separate papers of tho Bureau is as follows: 
L.C. \# $625-\# 3$

RP = "Rosearch Poper". These are reprints of articles appearing in the "Bureau of Standards Journal of Research" (BSJ. Research) and the "Journal of Research of the National Bureau of Standard.s" (J. Research NBS), the latter being the title of this periodical since July, 1934 (volume 13, number I).

S = "Scientific Paper" of the National Bureau of Standaras. From lios. I to 329, inclusive, the separate papers of this series were known as reprints from the "Bullet in of the Bureau of Standards" (BuI.BS). Subsequently, from Nos. 330 . to 572 , the separates were known as reprints from the "Scientific Papers of the Bureau. of Standards" (Sc1.Pap.BS). This series was superseded by the "Bureau of Standards Journal of Research" in 1928.

$I=$ "Technologic Paper" of the. National Bureau of Standards. Nos. I to 202 were issued each independent of the other with individual pagination. Later they vere. assemblç to make the first 15 volumes of this series, and subsequent separates were givon volume pagination. (Tech. Pap. BS). This series was supersedca by the "Bureau of Standards Journal of Rescarcht" in 1928 .

$c=$ "Circular" or tho National Bureau of Stancards.

$L C=$ Mimeographed "Lettcr Circular of the National Bureau or Standares".

PHR $=$ Public Ilealth Reports, issued by the U. S. Public Health Service, Fecleral Security Agency.

$$
\text { Published } \frac{\text { IIST "A" }}{\text { by the Government }}
$$

Reí

19.0. Pitle Year Series Pric

I Relation betveen composition, and density of aqueous solutions of copper sulfate 1916 \& 275 $\mathrm{OP}$ and sulfuric acic, Hollen, $\mathrm{F}$. J. and Peffer, F. I. BuI. 3S 13, $273(19,16-17)$

2 Black nickei ploting solutions, Nogabloom, G. B., Slattery, I. F., and Han, L。3. Tech。' Pap. 3S 15, (iǵ21).

3 Zinc cyaniae platine solutions, Bium W., Liscomb, $F^{\prime} J .$, and Carson, C. M. $1921 \geq 190$ $O P$ Tech. Pap. IS 15, (1921) 
L.C. $625-\# 4$

$\operatorname{Re} \dot{0}$.

No.

4 Electrodeposition of chromium from

chromic acia baths, Haring, Ii. $\mathrm{E}$.

$1927 \div 346 \cdot 15 \mathrm{c}$.

and Barrows, W. P. Tech. Pap.3S 2I,

$413(1926-27)$.

5 Health hazardis in chromium plating,

Bloomfield, J.J. (Public Health Service) and 3 Ium, $N$, Public Health

Reports 43, 2330 (1928).

6 Reflecting nower of beryllium, chromium, and several other metals, Coblentz, W.W. and Stair, R. BJS Research 2 , 343 (1929).

7 The spottine of plated or finished metals, Barrows, W.P. BSJ Research 2, 1085 (1929).

8 Throwing powẹ in chromium plating,

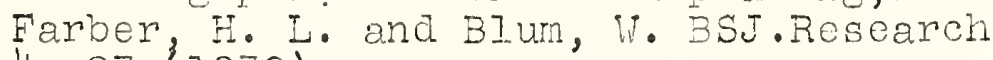
4, 27 (1930).

9 Conductivity and density of chromic acid solutions, Moore, HoR. and BIum, W. BSJ. Research 5, 255 (1930).

10 Copper,olectrotyping, Cir. BS 387 (1930)

I1 Addition agents in copper electrotypine solutions, Full, R.o. and Blum, W. BS J. Research 2,767 (1930).

12 The making of mirrors by the deposition of metal on glass, Cir. BS 389 (1931).

13 The resistance of chromium-plated gages to wear, Herschrann, H. K. BS J. Research 6, 295 (1931)

14 Dimensional chanes in the nanufacture of electrotypes, Bekkodahl, M. and BIum, W. BS J. Research 6 (1931)

1930 RP I3I. OP RP 1980 OP

1929 RP 39 OP RP 72 OP

$1928 \operatorname{PHR}_{1245} 5 \mathrm{c}$. 
L. C. $625-\# 5$

Ref.

No.

16 The porosity of oicctroplated chromium coatings, Blum, $W_{\cdot}$, Barrots, W. P., and $1931 \mathrm{RP} 368 \quad 10 \mathrm{c}$. Bremor, A. BS J. Research I, 607 (1931)

17 The analysis of cyanide silverplating solutions, Wict, R. M. BS J. Rescarch $R P 384 \quad O P$ I, $913(1931)$.

16 The structure of the chromic acid platine bath: The theory of chromium doposition, Kasper, C. BS J. Rescarch $2,353(1932)$.

19 A metal-connected elass eloctrode, (For pH moasuremonts), Thompson, M.R. BS J. Rescarch 2, 833 (1932).

20 The deposition of chromium from solutions of chronic and chromous salts Kaspor, C. BS J.Research 11, $515^{2}$ (1933).

21 Protective valuo or nickci and chromium plating on steol, Blum, 1. , Straussor, P.W.C., and Bronnon, A. J. Roscarch INBS 13, $33 i$ (1934)。

22 Accolerated tests of nickol and chromium plating on sicol, Straussor, P.W.C., Bronnor, $A_{\text {. }}$, and BIum, W. J. Rescárch irBS 12, $519^{\circ}(19 ; 4)$.

23 Nochanism of chromium deposition from tho chroric acid bath, Kaspor, C. J. Roscanch INBS 14, 693 (1935).

24 Moslo's chord mothod for mosuring the thicknoss of motal coatings, BIum, W. and Bronnor, A. J. Rosearch NBS I6, $171(1936)$.

25 Corrosion-protoctive value of clectrodoposited zinc and cadmium coatings on RP 611 $1932 \operatorname{RP} 476$ atcol,.Blum, W., Straussor, P.W.C., and Bronior, A. J. Rescarch NRS 16, 185 $(1936)$.

26 Fapid olcctrodeposition of iron. From forrous chloride baths, Kasper, $\dot{c}$. J. Rescarch N3S 18, 536 (1937). 
I.C. $-\# 625-\frac{4}{\pi} 6$

Ref.

No.

Title

Year Series Price

27 Magnetic method for measuring the

thickness of nickel coatings on ron-

1937 RP 994. $10 \mathrm{c}$.

magnetic base metals, Brenner, A.

J. Research NBS 18, 565 (1937)

28 Magnetic method for measuring, the

thickness of nonnagnetic coatines

1933 RP I081 $5 \mathrm{c}$.

on iron and steel, Brenner, $A$.

J. Research N3S 20, 357 (1938).

29 Salt spray tẹst, Mutschler, W. H.

Buzzarc, R. $W_{\text {. }}$, and Strausser,P.W.O.

LC 530 free

July $1,1938$.

30 Dropping tests for measuring the

thickness of zinc and cadmium coat-

1939 R.P $124010 \mathrm{c}$.

Ings on steel, Erenner, A. J. Re-

search NBS 23, 387 (1939).

31 Methods of measuring pH in alkaline

cyanide plating baths, Thompson, M.R.

J. Research NBS 24, 423 (1940).

32 Outdoor exposure tests of electro-

plated nickel and chromiun coatings

RP 12935 c.

on steel ana nonferrous metals, Blum,

W. and Strausser, D.W.C. J. Research

NBS $24,443(1940)$.

Foderal Specifications "Folating to Electroplatine.

Federal Specifications nay be obtained by sending the list price (not stamps) to the Superintenden of Documents, Govornment Printing Offico, Washington, D. C. DO $\mathbb{M O I}$ sene money to the National Buroak of Stondares.

Re?.

No.

Title

Plating
Referonce

Series Date

Price

201 Solts, las; stoel(Iacscrews)

202 Harciware; buizaers'

(nontemplate)
Zine

cadnium

Hickel, crromium

on non-

ferrous

metals

richol

chromium

zine, on

steel
$F F-3-5618 / 27 / 37$ $5 \mathrm{c}$.

FE- $\mathrm{H}-101 \quad 6 / 19 / 30$

(surer-

soclod by

FF-H-106

111

$116 a$

121a) 
L.C. C.625- $\frac{13}{7} 7$

Ref. Plating

No. Titie Beference

203 Hardwero, builders'; Nickol,

Locks ane lock-trim chromium

$F F-H-206$

on non-

ferrous

metals.

Nickel,

chrónium,

zine,

cadmium

on stec..

20ja Hardware, builacrs'; as abovo

Door-closers.

204 Fardraro, buildors'; shelf, and miscollancous

Nichel, chronium

on non-

ferrous

netals.

Nickel,

Chromiun,

zinc,

cacmiurn

on stocl

205 Harcware, builders'; As abovo hinges

206 Harciware and fittings, (for) lavatory pertittons and inclosures.

207 TumbuckIes

Nickol, chromium on brass and bronzo

$P F-116 a$ $8 / 19 / 30$ Prici Series EF-12Ia $4 / 12 / 37$ $5 c$. $F F-I-I I I$ $8 / 19 / 30$ $10 \mathrm{c}$ 5 c. Zine, cacmiun on steol. 208 Salts; nickel (for) elcctroplatine and electrotyping

itickeI

sultatio

itickel ammonium sulfate. lickeI chloride

$F F-\mathrm{F}-136 \quad 10 / 29 / 36$ $5 c$

Silver plating $F E-19-791$ $2 / 10 / 37$
$0 / 29 / 36$ $10 \mathrm{c}$ Chromium, RR-I-56 $8 / 22 / 41 \quad 5 \mathrm{c}$. 221 Tableware; steel.

220 Iableware; silver-
ploted

220 Iableware; silver-
ploted nicleel, silver and tin plating;
Riz-I-5Ia $6 / 5 / 34$

$5 c$. $0-5-61$ $5 / 27 / 30$ $5 c$. 
L. C. $625-$ it 8

Ref. Titi

ivo.

Plating Series Date Price

22la Emergency Alternate

Federal Specitzcation

Por Tabletrare; Steel.

23 outlet boxes; steel cadmiun or zinc

coated, vith covers

and accessories

232 Conduit; steel

rigid, zinc-coated

233 Plumbing fixtures; (for) land use.

234 Tubing, electrical metalisc

235 Unions; brass or bronze, 250 lbs.

236 Valves, radiaton; air, thermostatic (eravity steam heating systoms)
Reference

\begin{tabular}{|c|c|c|}
\hline $\begin{array}{l}\text { Silver } \\
\text { platine } \\
\text { only }\end{array}$ & $E-R R-T-56$ & $5 / 20 / 42$ \\
\hline $\begin{array}{l}\text { Cadmium, } \\
\text { zinc } \\
\text { on steel }\end{array}$ & $w-0-621 a$ & $6 / 10 / 37$ \\
\hline
\end{tabular}

zinc on W-c-5zica 5/7/35 5 c. steel

Nickol; chromium on brass and bronze.

zinc on steel.

$W T-P-541 a$

$3 / 30 / 40$

$15 \mathrm{c}$.
$1 / 0 / 35$

steel.

Nichel, chro-Wi-U-516 mium on brass

Nickel, chro- WW-V-I5I mium on brass Outsice Publicntions (available only. In libraries).

$\operatorname{Ref}$ Title Year

iNo.

301. Preliminary. studies in the deposition of copper in

1916

electrotyping baths, 31 um W., Holler, H.D., and

Rawaon, H.S. Trans. Ar. Electrochem. Soc: 20,159 $(1916)$.

302 Factors governing the structure of èlectrode1919 posited metals, 3lum, "Vo Trans. An. Electrochem. Soc. $36,213(1919)$.

303 Lead plating from fluoborate solutions, Blum, W. Liscomb, F.J.; Jencls, Z., Bailey, W.I.Trans. Am. Electrochem. Soc. 36, 243 ( 1919 )。

304 The embrittine effectis of cileantine and picking.

1920 upon carbon steels, Lungaion, S.C. and Grossman, M.A. Trans. An. Electrochern. Soc. 37, 543.(1020). 305 The use of Iluprides in solutions for nickel deposition, BIum, W. Irans.Am.Electrochem. Soc. 29, 459 (1921). 
L.O : $-\# 3$

Ref.

No.

306 Tie.structure and properties of alternately olectrodeposited metals, BIum, W. Trans. Am. Electrochen. soc. 40, $307 .(1921)$

307 The oloctrodeposition of iead-tin alloys, Biun, $i$ and Haring, E. E. Mrans. An. Electrochen. Soc. $40,287(1921)$

308 The electrolytic reprocuction of engraved printing plates, Blum, $W$ and Slattury, T. F. Chem. \&et. Eng. 25, 320 (1921)

309 The actity of nickei depositing solutions, Thomp1922 son, M.R. Irans. An. Electrochem. Soc. 41, 333 (1922).

310 The effect of impurities innickol salts used for elcctrodonosition, Thompson, M.R. and Thomas,C.I. Irans. Am. Electrochem. Soc: 42, 79 (1.922):

31 The influence of the base metal on the structure of electrodoposits, BIum, W. and Rawdon, H. S. Trans. Am. Electiochen. Sọ, 44,305 (1923).

312 Current distribution and throwing power in elec-

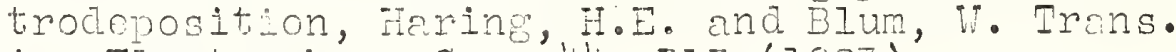
An. Electrocher. Soc: 44,313 . (1923).

313 Tho.orfect of iron on the olectroceposition of nickel, Thompson, M. . . Trans. Am. Electrochom. Soc. $44,359(1923)$.

314 Tho.crystrilino form of electrodepositod motals, Blum, w. and Rawdon, H.S. Trans. An.Elcctrociem. Soc. 44, 397.(1923).

315 Recent progess in olectroplnting and oloctroforming, Blum, $W$. Irans. Am, Flectrochom. Soc. 45, .

316 Nicrel anodes, Thomas, C.I. and Blum, W. Irans. An. Electrochem. Soc: 45, 193 (1924).

317 Electroplating worn machine cun barrels, de Svensinikoff, W.W. and, Haring, H.E. Amy ordnance 2, 503 (1924). 318 Conductivity of nichel depositine solutions, Fammond, I.D. Trans. Am. Electrochem. Soc. 45,219 (1924).

319 Fluorine deternination in nickol depositine solutions, Mamona, I.D. Ine. Enc: Chen. 16, 930 (1924). 320 Throwine power, crthode potentials and efficiencies in nickel cepositjon, Haring, H. Z. Irans. Ar. Dlectrochem. Soc. 46, 107 ( 1924$)$.

321 Princios and onerating conditions op chromium plat- 1925 ing, Haring, E. E. Chem. \& Mot. Dine 22, 692 (1925).

322 Electrolytes end ionocens, 3lum, i. Trans. An. Electuocher. Soc. 47, $123(1.925)$.

323 The niclel. pleting of zinc and zinc-base dic-castings, Thompon, M.R. Trans. Am. Electrocher." Soc. 4], $163(1925):$

324 Tenchine principles or electrodeposition, Jlum, $W$. J. Chom. Eauc. 
I.. O : $-\frac{\| 1}{\pi} 10$

Rer.

ivio.

325 The protective value of nichel plating, Thomas, c.I. and Blun, N. Trans. Am. Electrochen. Soc. 48,69 $(7225)$.

326 Note on the protection of iron by cacmium, Rawdon, ii.S. Trans. Am. Electrochem. Soc. 49, $339^{\prime}$ (1926).

327 A simple nethod for measuring polarization and resistivity, Horine, H. Trans. Am. Electrocher. Soc. $49,417(1926)$.

320 Futuro tronds' in clectrochenistry, 3lum, W. Ina. Es Eng. Chen, 18, 1026 (1926). Acic zinc plating baths, Thompson, M.R. Trans. Am. Electrochen. Soc. 50, 193 (1926).

330 Protection against corrosion by neans of metallic

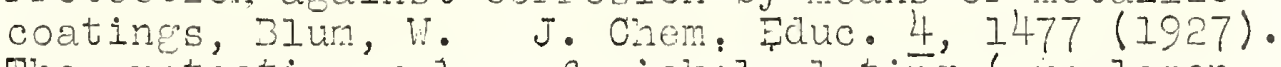

331 The protective value of niclel plating (supplomental observations), Thomas, C.T. and BIum, T. Trans: Arg. Electrochem. Soo: $22 ;$. 271. (1927).

332 Principies or ilectrolytic studics on corrosion, Blum, Wo and Rawaon, H.S. Trans. An. Electrochen. Soc. $52,403,(1927)^{\prime}$.

333 Eloctroplating (In the autonobile incustry), 3lun, W. Inc. Eng. Chom. 19, 1111. (10,27).

334 Mote on the cristal structure of electrodoposited chromiun, Sillers, F. Irans. A . Electrochem. Soc. 迆, 301 (1927).

335 Nickol blectrotyping solutions, Blum, w. and Winlicr, J.H. Trana. Am. Electrochon. Soc. 23, 419 ( 1928$)$.

336 The propertios of erephite used in clectrotyping, Wintior, J. H. and 3lum, $U$. Trans. Am. Eloctrochem. Soc. 53,435 (192\%).

337 Colloids in tho oloctrodoposition of motals, Blum, W. Colloid Symposiun, p. 301 .

358 Mechanical applications of chromium platine, 3lum, W. Mech. Eng. 50, 927 (1928).

339 The measuroment of $\mathrm{DH}$ in rickcl plating solutions, Blum, $\mathrm{W}$. and 3olkedahl, N. Trane. An. Electrochem. Soc. 56, 291 (1929).

340 The production or electrolytic iron printing plates, 1930 Thomas, C.I. and Blum, W. Trans. Am. Electrochom. Soc. 51, 59 (1930).

341 Applications of chromium platine in the graphic

342 arts, Blum, W. Typothetae Bul. (November 10, 1930). 1931 Metals \& Alloys ? 5 ? (1931).

342a. The titration of Iroe cyanide in copper, baths, Thompson, M.R: Konth. Rov. Am. Eloctroplaters' Soc. 18; ( $\mathrm{Nay}, 1931)$.

343 Cyanices in metaliurgy, Thompson, M.R. Trans. Electrochem. Soc. 60, 35 (1931). 
$\pm: C:-\frac{21}{\pi} 11$

Ref.

No. Nitio

344 The definition and detemination of free cyanide

1931

in elcctroplating solutions, 3Ium, W. Trans.

Elcotrochem. Soc. 60, 143 (1931).

345 Tho status of chromium plating, Blum, *. J.

Frankin Inst. 213, 17 (1932).

346 The. decomposition of cyantde solutions, Month. Rev.

$19 ; 3$ An. Electroplaters' Soc. 19, (April, 193j). Vick, R. . .

347 Mẹthoas of stripping platud coatings, Month. Rev. Am. Electioplaters'. Soc. 20 (November, 1933), A. Brennor.

348 iotós on cyaniac solutions, iick, R.H. Month. Rev. An. Electroplaters' Soc. 20, (June, 1934).

349 Notes on the analys of alsaline tin pleting solutions, Thompson, R.R. Month. Rev. Am. Electropleters' Soc. 20 (June 1934).

350 Testing of plated metals for compliance with Federal Specifications, Thompson, M.R. Month. Rev. Am. Electroplateri' Soc. 21, (September, 1934).

351 The definition of polarization, overvoltaes, and decomposition potontial, Blim, W. and Vinal, G.i. Irans. Electrochem. Soc. 66, 359 (1934).

352 The stirueture and physicnl proportics of nickel de-1935 positea at high curront donsitios, 3lum, W. and Iasper, C. Trans. Farada Soc. 31,1203 (1935).

353 Dropine tests for deternining the local thichess of zinc anc çamium coatings, Iull, R.o. and Strilussor, P.T.C. Month. R.CV. Am. Electroplators' Soc. 22, (March 1935).

354 The use of color photography for recording the results op exposure țests, Vincent-Daviss, C.A. 'and BIum; W. Month. Rov. Am. Elcctroplators' Soc. 24, उ18 $(1337)$.

355 Laboratory tests of olcetroplated coatings on nonferrous metals, Strausser, P.U.C. Month. Rcv. Am. Electroplaters ${ }^{i}$ Soc. 24, $322(1937)$.

356 Nagnotic mothod for masuring the thicknoss of. niclol coatines on nonmasnotic baso metals, Bronner, A. Month. Rev. A-. Eloctroplators'soc. 25, $252^{\prime}(1933)$.

357 Vagnetic motioç for measuring the thickness of non-. magnetic coatines on iron anc steel, Bronner, $A$. Nonth. Rcv. Am. Electroplaters Soc. 25, 261 (1938). 
L.C: $625-\frac{4}{\pi} 12$

R०⿱宀㠯十.

No.

358 Current distribution in.eloctrodoposition.

I. Linear, eylincrical and sphorical conduc- ..

tors, Kasper, C. Month. Rev. Am. Electro-

platers' Soe. 26, II (1939).

359 Current distribution in electrodeposition.

II. Point-plane and Iinc-plano systems, Kasjor,

C. Month. Rev. An. Electroplaters' Soc. 25,

91 (1939).

360 Porosity tests. for nickel coatings on steel,

Straussor, P.W.C. Convention Proc. Am. Electro-

platers Soc. I. 194 (1939).

361 The measurement of $\mathrm{pH}$ in alhaline plating solutions, Thompson, M.R. Convention Proc. Am. Electroplaters' Soc. p. 200 (1939).

362 Some.effects of anocte shape and position upon cathode current distribution, Kasper, C. Convention Proc. Am. Fiectroplaters' Soc. p. 209 (1939).

363 A study of silver plating for industrial.applications, Dornblatt, A.J., Lowe, C.S., and Simon, A.C. Convention Proc. Am, Elęctroplatersi Soc.p. 214 (1939).

364 Dropine tests for zinc and cacmium on stecl, Bronner, A. Convention Proc. Am. Electroplaters Soe. p. 204 $(1939)$.

365 The theory of the potontial and the technical practice of electrodeposition. I. The general problem and the cases of uniform IJow, Kasper, O. Trans. Electrochem. Soc. 17, $353 .(1940)$.

366 The theory of the potontial and the technical practice of clectrodepogition. II. Point-plane and Iine-plane systems, Kasper, C. Prans. Dleetrochem. Soc. 77,355 (19,40).

367 Notes on, the spot test for thickinoss of chromium coatings, BIlm, W. and OIson, W.A. Convention Proc. Am. Electroplaters' Soc. J. 25 (19,40).

368 . Sitror piateng at vory high curront donsitios, Simon, A.C. and Lumloy, J.I. Convention Proc. Am. Electroplatons' soc. p. if $(1,2,0)$.

369 A method for study inc cathode rilns by proozine, Bronner, A. Convontion Proc. Ar. Electroplaters: Soc. p. $95(1,40)$.

370 The theory of the potontial and the technical practice of electrodeposition. III. Lincar poinrization on some Iinc-pzane systems, Kaspor, C. Frans. Zloctrochon. Soc. 78 , proprint $(1940)$ :

371 The thoory of tho potontial and the technical practice of clectrodeposition. IV, The rlow between and to circular cylinders, Kaspor, C. Mrans. Electrochom. Soc. 70 , proprint $(1940)$. 
372 What metals can be deposited from aqueous solutions? 'Blum, T. Month. Rev. Am. Electroplaters' soc. $27,923^{\prime}(1940)$.

373 The.constitution and properties of cyanide plating baths, Thompon, $1 \cdot \bar{A}$. Irans. Electrochem. Soc. 79,417 (194i).

$$
\text { วolisine stool sijecimon }
$$

374 Polisine stool specimens pirior to.plating for oxposure tests, Lux, Gerald A. Convention Proc. Arn. Electroplaters 1 Soc., p. 54, 1941.

375 Effects of motal shortakes on the platine incustry, 1941 Blum, $w^{\circ}$ Convention Proc. Ancr. Blectroplaters' soc., p. 6, 1941.

376 Platine relieves netal shortaces, jium, W. Chem. \& Met. Ene. 48, $70^{\circ}$ (1941). 377 Genoral principies and methods of eleetroplating
3Ium, W. Irans. DIectrochom. Soc. 80, 249 (I941)

378 Lcad platine, Gray, Allén ond Elum, $W^{\circ}$ Trans. Eloctrochem. Soc. S0, 645 (1941).

379 Substitution of iron for nidiel and copper in printing plates, Lamb, Vemon A. ond Blum, W. Technical Bullotin No. 7, issued April.15, 1042 by the Internetional Association of Electrotypors \&: Storcotypers, Clevoland, Ohio.

380 The theory of the potontial and the tochnical practịce of olectrodorosition. V. Tie Tro-. dinensional rectoncular onclosures, Masper, Charies. Trans. Eloctrochom. Soc. Sa, propint (1942).

\section{LESI"}

Geneml Sources of Information in English.

Numerous articles on electrodeposition vill be found in such journals as:

Transactions of the Electrochenical Society

Trancactions of the Faraciuy Society

Monthly Review American Electroplaters' Society Joumal Electrodepositors' Tecinical Society (Iondo Metn Finishing (NTew Yoris)

retal Industry (Londion) 
I.C. $625-\frac{14}{\pi} 14$

Amone tre recent books in Englișh on electrodeposition are:

Lancoein, G. and Brannt, W. T., Eiectrodeposition of metals; (Henry Carey Bairci anä Co., ơth Ë., 1920). Dedell, W.L.D., PractHcal olectroplatine (5th Da., 1923) Fughes, W. E., Modern electroplating (Oxford Technical Publications, 1923).

Field, S. and Sonney, S.R., The chemical coloring of metals, (Chapman and Hali, Lta., 1925).

Frecman, D. and Foppe, F: G., Electroplating with chromium, copper, and nickel. (Prentice-Hall Co., 1929).

31 un, W. and Hogaooom, G.J., Principles of electroplating and electroforming, (Inckret-Hill jook Co., 2a od., 1930).

Fiela, S. and.Weill, A. E., Electroploting (I. Pitman and Sons, Lta.; 1930 .

Richards, E.S., Chronium plating (J'J.Lippincott Co.,1932)

Bawer, 0. , Arndt, I., and Krause, W., Chromium platine. Enclish transiation by Parkor, E.T. (Edward Arnold and Co., 1935).

\section{INDEX}

In the following list, cach publication is referred to by the refercnce number, by wiicis it is listed in the rirst column in the preceatine pages oi this circular, in which are given explicit reforerces, and directions for ordoring Govornment publications.

Accoleratca tests

Adhesion of olcetrocicposits

Altornato donosits

$$
22,25,29
$$

$-32$

306

Anodos

Chromium plating

Nickel

316

311

2

Brass, protoction by

Iicrel

Chromiun

Cadmiun, protoctivo value on steel
32
32 25,326 
Cathode rilm composition

Chord mothod for thäcluness

Chrorium doposition
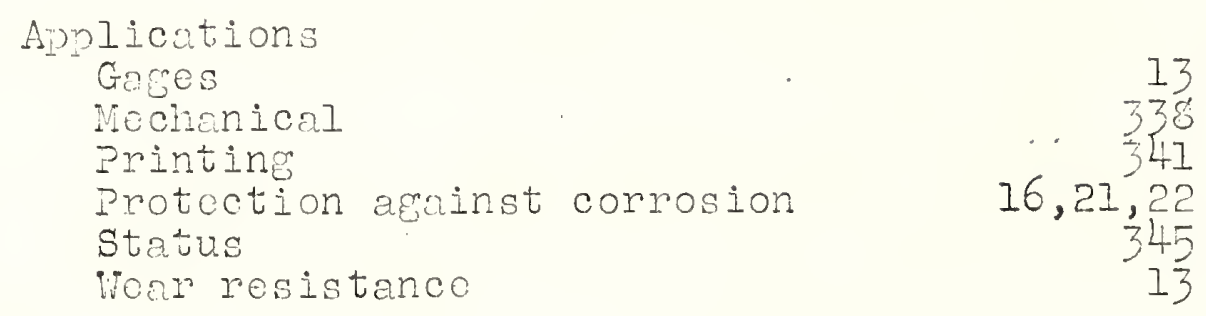

Baths

Chiomic acid

Conductivity

Donsity

Eealth hazards

Structure

Theory

Throwing power

Chromic salt

Chromous salt

Donosits

iscolorated tojts

Appeciranco

POrOsity

Protoctive valuo

Eoflocting power

Specifications

$202,203,204,205,206,233$

Structure

Thicknoss neasuronont

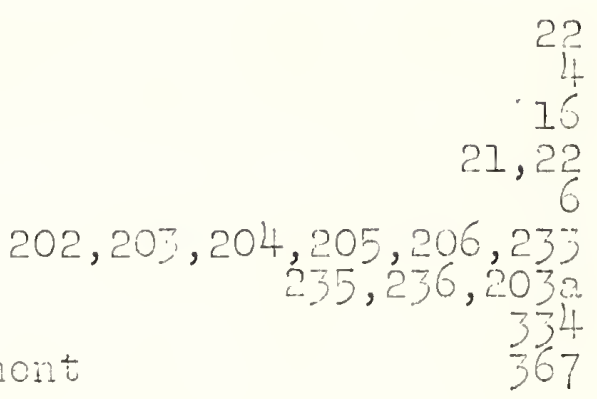

Cloaning stcol. (ombrittine offoct)

304

Colloids in olcctrodoposition

337

Conductivity of solutions

Chromic acia batis

Mothod of monsurement

wickel baths

zinc baths

$318,320,32 \frac{32}{32}$

coppor denosition

Acic batis

Adituson agents

Denisity

Elccurotypine

on silverea klass

Throwing poter

Iypical comosition

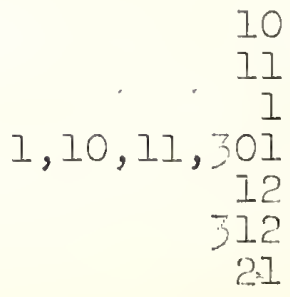


L. C. $625-\frac{475}{71}$

Coper deposition

Cyanicie baths

Analysis

Throwing power

Typical composition

Corrosion

Principles

Protection agrinst, by platine

$21,22,25,325,332$

Crystal spottine

Current distribution

$358,359,362,365,366,370, \frac{371}{380}$,

Cyanides

Analysis

Constitution of solutions

Decomposition

Free cyanide, definition

Free cyanice, titration

Purification

Uses in metalzurgy

$$
\begin{array}{r}
75,77,342 a \\
344,349,373 \\
346 \\
344,373 \\
342 a \\
755 \\
343
\end{array}
$$

Decomposition potential, definition

351

Dropping tests, thickness of zino and calmium

$25,30,353,364$

Electroceposition

Future trends

Teachine principles

Electrolyte, definition

Electroplating

Adhesion of deposits

Autonobile incustry

Progress

Protective value

scope of

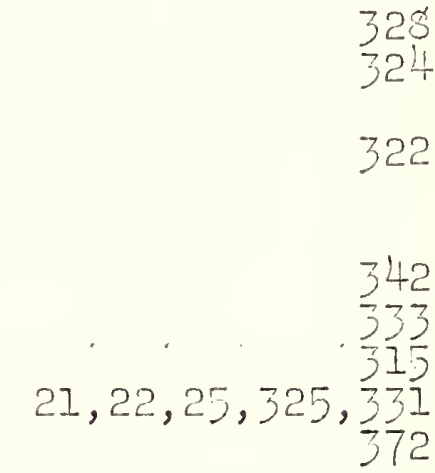

Electrotrpine

Coper baths

Dinensional chances

Graphite

Yictel boths

Emonitting steel

304

Exposure tests

$$
21,25,325,331
$$

Ferroxyl test $22,32,325,331,360$

Fluorides

Determination in nicrel baths

Use in nickel baths 
I.C. $625-\ddot{\pi} 17$

Froezing catroce films

Gages, chromium plated

Glass eleotroce, for pF measurement

Graphite, for electrotyping

Gun barrels, eleatroplating

Nordware, plating specifications $203 a, 202,203,204,205,206$

Fealth hararis, chronium plating

Ionocen, definition

Iron

Denosition

Efrect in nickel deposition

Printing plates

Intermittent immersion test

Lead deposition

Lead-tin alloy deposition

\author{
$26,340,379 \frac{9}{3}$ \\ $-40,379$ \\ $22,25,325,331$ \\ 303,378
}

307

27,356

28,357

375,376

12

Mirrors, silverine and platine on

riaciel ceposition

Anocles

Baths, typical

Acicity

Cathoce efficiency

Cathoce potential.

Conductivity

Efrect of iron

Fluorides in

Impurities in

Ploting on zinc

$\mathrm{PE}$

Polarization

Throwine power

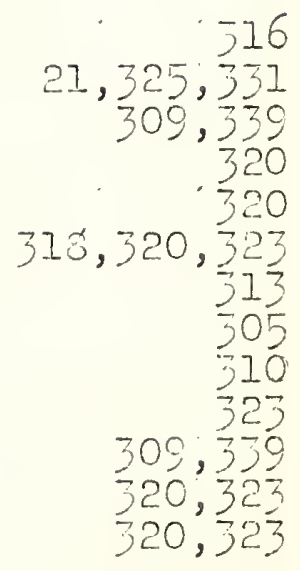

Black nickel lating 
L.C. $625-\# 18$

Deposits

Accelerated tests

High current density

Protective value

Thickness, magnetic measurement

$21,22,325,331,355, \begin{array}{r}22 \\ 352 \\ 260 \\ 357,28,355,\end{array}$

Salts (ivichel)

Impurities in

Specification

Overvoltake, definition

351

Dif measurements

Alkaline baths

Giass olectrodo

Nickel baths

Zinc baths (acid)

Pickling, emoritting effect on steel

Plumbing fixtures, plating speciftcations

Dolarizetion

Dofinition

Necsurement

:ickel baths

zinc baths

Polishing steol

Porosity of coatines

Prineiples of plating

Printing plates (soe also eloctrotypins)

Chromium plated

Electrolytic roproauction

Iron deposition

Protection against comrosion

Rare motal doposition

Rosistivity of solutions

Chromium batis

Hethod of measuromont

ivicleal baths

Zinc batho 
ב.C. $625-\frac{4}{\pi} 29$

SiIVer pleting

AnIJsig of baths

ADr Lications

Raj ic.

Siccipications

Specirlcations (Federal)

Nickel salts

Builders' hanclware

Electrical equipment

Plumbine fixcures

Silver lated tableware

rostin for confomance

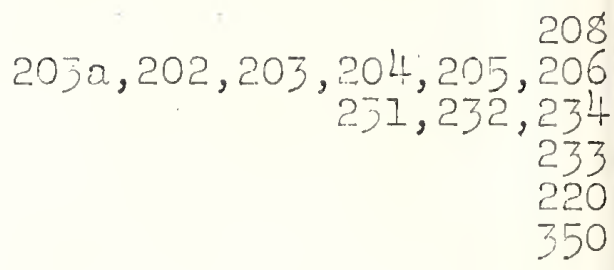

Spotting out

Spot test por chromiun

Stain spotting

Steel

Enbrittzing by pickling

Gaces, chromium plated

Polishine

Protection against corrosion by

Cacinium

Chromium

MicireI

zinc

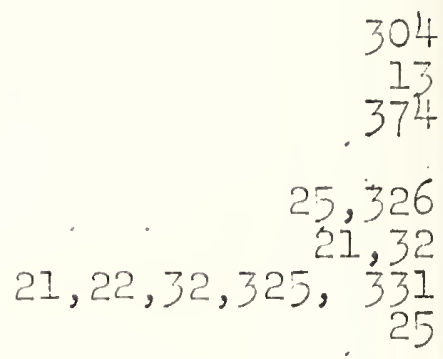

Stripoine electrodeposits

347,355

Structure of electrodeposits

$26,301,302,306,311,314,352,377$

Thickness or deposits, measurement

Choid methor

Drompine netiod

Magnetic methods

Spot test

Stripping rethods

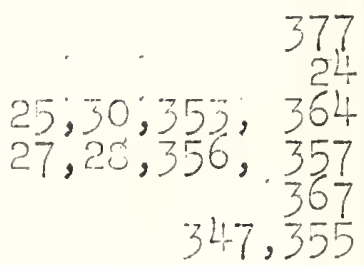

Throwing pover

Chronium platinE

Definition

Measurenent

liclrel plating

zine platine

347,355

Tin plating

Analysis of baths

Zine

Batis

Acic

Cyaniaje 
L.0. $625-\frac{4}{\pi} 20$

Zinc

Plating nickel on zine

32,323

Protection by

Nickel

32

Chronium

Protective value on steel 
